\title{
Strategie i metody przekazywania francuskiej opinii publicznej relacji o terrorze stalinowskim za żelazną kurtyną na przykładzie procesów sądowych z lat 1949-1952*
}

\begin{abstract}
Abstrakt: We Francji w początkach zimnej wojny sala sądowa stała się miejscem debat, podczas których dyskutowano o rzeczywistej naturze reżimów za żelazną kurtyną. W niniejszym tekście starano się wyjaśnić, dlaczego tak się stało i omówiono kolejne procesy wytaczane francuskim komunistom przede wszystkim w celu poruszenia opinii publicznej. Próbowano również wskazać, czemu i w jaki sposób jedni spośród skarżących zdołali osiągnąć swoje cele, a inni nie.
\end{abstract}

Słow a kluczowe: Francja, zimna wojna, komunizm, emigracja, procesy.

Abstract: In France, at the early stage of the Cold War, the courtroom became a forum of debates about the real nature of regimes behind the Iron Curtain. The author seeks to explain the reasons for this phenomenon and discusses successive lawsuits brought against French communists mainly to touch the general public. Attempts have also been made to explain why some of the accused were able to reach their objectives while others failed.

Keyw ords: France, Cold War, emigration, trials.

W powojennej Francji ogromnym prestiżem cieszyli się zarówno bojownicy rodzimego komunistycznego ruchu oporu (Résistance), jak i Armia Czerwona.

\footnotetext{
* Niniejszy artykuł powstał dzięki dofinansowaniu z programu Ministerstwa Nauki i Szkolnictwa Wyższego pod nazwa „Narodowy Program Rozwoju Humanistyki” w latach 20122014.
} 
W Związku Sowieckim upatrywano głównego twórcy alianckiego zwycięstwa ${ }^{1}$. Na fali tej sympatii Francuska Partia Komunistyczna (FPK) wygrywała kolejne wybory w latach 1945-1946. Lewicowi intelektualiści, którzy zdominowali ówczesne życie kulturalne Francji, widzieli w komunistycznych aktywistach dawnych męczenników walki za sprawę. Natomiast wydawnictwa antysowieckie kojarzono wówczas przede wszystkim z nazistowska propaganda oraz z działalnością kolaborantów, takich jak np. jak Paul Chack, twórca Komitetu Przeciwdziałania Antybolszewickiego ${ }^{2}$. Wydaje się, że francuscy politycy, którzy pragnęli, by ich kraj utrzymał rolę pośrednika pomiędzy Wschodem a Zachodem, nie odczuwali potrzeby zmieniania tego stanu rzeczy ${ }^{3}$.

Dlatego też książki o terrorze stalinowskim pozostawały wydawnictwami niszowymi. Część z nich opublikowano poza granicami Francji. Pierwsza francuska edycja Folwarku zwierzęcego ukazała się w Monako ${ }^{4}$. Natomiast francuskie przekłady polskich książek o terrorze stalinowskim żołnierze 2 Korpusu przygotowywali i oddawali do druku na terenie Włoch. Należała do nich m.in. La Justice soviétique (Sprawiedliwość sowiecka) Sylwestra Mory (pseud. Kazimierza Zamorskiego) i Piotra Zwierniaka (pseud. Stanisława Starzewskiego), stanowiąca w połowie opracowanie specjalistyczne na temat sowieckiego systemu karnego, a częściowo będąca wyborem polskich relacji łagrowych ${ }^{5}$. Początkowo polskie wydawnictwa nie wywołały większego odzewu, bo trudno za takowe uznać pojedyncze recenzje ukazujące się $\mathrm{w}$ pismach niszowych i specjalistycznych ${ }^{6}$.

Trzeba przyznać, że pierwsze książki, którym udało się w pełni przebić przez zasłonę milczenia, były dziełami lewicowych twórców. Orientacja polityczna autorów uwiarygodniała ich relacje i stanowiła antidotum na brutalne ataki komunistów, którzy stale oskarżali krytyków realiów sowieckich o faszyzm, reakcjonizm bądź zacietrzewioną wrogość wobec ZSRR 7 .

${ }^{1}$ O podziwie dla Związku Sowieckiego zob. M. Mikołajczyk, Polityka Francji wobec ZSRR $w$ latach 1944-1955, Poznań 2004, s. 31. O wyolbrzymianiu roli komunistów w ruchu oporu i szacunku, jaki im to przyniosło, zob. E. Morin, Autocritique, Paris 1959, s. 76-77;

A. Beevor, A. Cooper, Paryż wyzwolony, tłum. J. Małecki, Kraków 2015, s. 10-11.

2 Odnośnie do Paula Chacka i jego działalności zob. P. Ory, Les collaborateurs 1940-1945, Paris 1976, s. 151-153.

${ }^{3} \mathrm{O}$ załamaniu się tych nadziei zob. ibidem, s. 94; D. Jarosz, M. Pasztor, Robineau, Bassaler i inni. Z dziejów stosunków polsko-francuskich w latach 1948-1953, Toruń 2001, s. 29.

${ }^{4}$ P. Rigoulot, Les Paupières lourdes. Les Français face au goulag. Aveuglement et indignations, Paris 1991, s. 51.

${ }^{5}$ Odnośnie do francuskiej edycji Sprawiedliwości sowieckiej zob. K. Zamorski, Dwa tajne biura 2 Korpusu, Londyn 1990, s. 219, 286-287.

${ }^{6}$ Zakład Narodowy im. Ossolińskich, Archiwum Kazimierza Zamorskiego, 21/01, List Kazimierza Zamorskiego do Siergieja Mielgunowa z 25 lutego 1947; J. Graven, Le droit pénal soviétique, „Revue de science criminelle et de droit pénal comparé”, IV-VI 1948, no. 2, s. 231-273.

${ }^{7}$ Przykładowo David Rousset obawiał się tych oskarżeń, kiedy dobierał świadków na swój proces antysowiecki. Zob. Instytut Polski i Muzeum im. gen. Sikorskiego (dalej: IPMS), sygn. kol. 401/24, Sprawozdanie Janusza Kowalewskiego z 14 grudnia 1949. 
I tak np. w 1945 r. wielkim sukcesem wydawniczym okazała się powieść Arthura Koestlera Le Zéro et l'infini (Ciemność w południe). Z ustaleń biografa Koestlera, Michaela Scammella wynika, że przynajmniej na początku wśród czytelników znajdowali także francuscy komuniści. Być może przemawiała do nich historia bohatera, który z uwagi na dobro partii przyznał się podczas wielkiej czystki do niepopełnionych win ${ }^{8}$.

\section{Sprawa Wiktora Krawczenki}

W 1947 r. czołowi francuscy politycy podjęli decyzję o przyłączeniu się przez Francję do bloku państw zachodnich, a przedstawicieli FPK wykluczono z rządu 5 maja. Zaledwie cztery dni wcześniej ukazał się na rynku francuskim jeden z największych bestsellerów wydawniczych okresu zimnej wojny, autobiograficzna książka sowieckiego niezowraszczeńca Wiktora Krawczenki zatytułowana J'ai choisi la liberté ${ }^{9}$. Jej autor porzucił w 1944 r. pracę w sowieckiej Komisji Lend-Lease Act w Waszyngtonie i postanowił zredagować książkę, w której opisał mroczne strony funkcjonowania państwa stalinowskiego - nie tylko wielki głód, wielką czystkę, łagry, ale i donosicielstwo oraz nierówności społeczne ${ }^{10}$. Zarówno w USA, jak i we Francji odniósł olbrzymi sukces wydawniczy, który skłonił go do kontynuowania walki z komunizmem. Te aspiracje sprawiły, że Krawczenko stał się pożądanym sojusznikiem tak dla amerykańskich, jak i dla francuskich polityków ${ }^{11}$. Prawdopodobnie któryś z zaprzyjaźnionych amerykańskich działaczy bądź mężów stanu namówił go, by zaatakował wpływową FPK, która była ambitniejszym celem niż jej amerykańska odpowiedniczka ${ }^{12}$.

\footnotetext{
${ }^{8}$ M. Scammell, Koestler. The indispensable intellectual, London 2009, s. 196-197.

${ }_{9}$ Odnośnie do daty publikacji książki Krawczenki zob. J. de Kardéland, Avertissement $n^{\circ} 2$ ou trente-trois ans après, w: V.A. Kravchenko, La vie publique et privée d'un haut fonctionnaire soviétique, Paris 1980, s. X. O wykluczeniu komunistów z rządu zob. P. Goetschel, B. Toucheboeuf, La IV République. La France de la Libération à 1958, Paris 2004, s. 180-181. Zdaniem Pascala Balmanda, który przywołuje listę największych francuskich bestsellerów powojennych - opublikowaną przez „L’Express” w 1955 r., książkom Krawczenki i Koestlera należy się odpowiednio trzecie i czwarte miejsce w rankingu. Zob. $\mathrm{P}$. Balmand, Les best-sellers de la guerre froide, w: Le temps de la guerre froide. Du rideau de fer à l'effondrement du communisme, éd. M. Winock, Paris 1994, s. 181.

${ }^{10}$ W. Krawczenko, Wybrałem wolność. Życie prywatne i polityczne radzieckiego funkcjonariusza, tłum. M. Antosiewicz, Warszawa 2009.

${ }^{11}$ Odnośnie do różnych sposobów, w jakie władze francuskie i amerykańskie wspierały sprawę Wiktora Krawczenki, zob. I. Wall, L’influence américaine sur la politique française 1945-1954, Paris 1989, s. 220-221; G. Malaurie, E. Terrée, L’affaire Kravchenko. Paris 1949, le Goulag en correctionnelle, Paris 1991, s. 50.

${ }_{12} \mathrm{O}$ ewentualnym namówieniu Krawczenki przez amerykańskiego polityka zob. G. Malaurie, E. Terrée, op. cit, s. 44-45. Odnośnie do opinii Krawczenki, iż FPK warto było atakować, zob. J. Nordmann, Aux vents d'histoire, Paris 1996, s. 175.
} 
Środkiem do podjęcia planowanej walki stał się proces o zniesławienie. Choć komunistyczny adwokat Joë Nordmann usiłował temu później zaprzeczać, to we Francji istniała długa tradycja wszczynania wielkich debat politycznych i etycznych (affaire) w ramach spraw sadowych. Najlepszym tego przykładem były procesy Dreyfusa i Émile’a Zoli ${ }^{13}$. Właśnie do tej tradycji chciał się najprawdopodobniej odwołać Krawczenko i trzeba przyznać, że stworzył pewien wariant takiej konfrontacji i znalazł później licznych naśladowców.

Pretekstem stał się dla niego artykuł zatytułowany Comment fut fabriqué Kravchenko?, który ukazał się na łamach komunistycznego tygodnika „Les Lettres Françaises” 13 XI 1947. Sowiecki dysydent został w nim oskarżony nie tylko o niezdolność do napisania własnej książki, ale również o pijaństwo, uzależnienie od hazardu i popadnięcie w długi u przedstawicieli amerykańskiego wywiadu ${ }^{14}$.

W odpowiedzi Krawczenko wniósł skargę o zniesławienie (18 II 1948). Obowiąujące wówczas prawodawstwo (a w zasadzie przede wszystkim ustawa o wolności prasy, pochodząca 1981 r., ale zmodyfikowana ordonansami z maja i września 1944 r.) pozwalało obu zainteresowanym stronom na przedstawienie dowodów i świadków ${ }^{15}$. Krawczenko wierzył, że w tych warunkach uda mu się zainicjować wielką debatę na temat rzeczywistości sowieckiej, choć jego własny adwokat Georges Izard początkowo w to powatpiewał ${ }^{16}$.

Ostatecznie to reakcja francuskich komunistów sprawiła, że nadzieje Krawczenki się ziściły. Najważniejszy adwokat FPK, Nordmann nabrał już $\mathrm{w}$ tamtym czasie pewnej rutyny w zakresie prowadzenia podobnych procesów o zniesławienie. Po odejściu komunistów od władzy wytaczano je bowiem bardzo często komunistycznym periodykom i gazetom ${ }^{17}$. Polski ambasador we Francji, Jerzy Putrament uznał je nawet za rodzaj kampanii majacej na celu zniszczenie „prasy postępowej” ${ }^{18}$. Niemniej Nordmann czuł się w swojej roli bardzo pewnie. Już wcześniej wygrał analogiczny proces o zniesławienie,

${ }^{13}$ Odnośnie do spraw sądowych Dreyfusa i Zoli zob. M. Winock, Le siècle des intellectuels, Paris 1999, s. 32-41; Affaires, scandales et grandes causes. De Socrate à Pinochet, ed. L. Boltanski et al., Paris 2007, s. 7-17, 213-227. Odnośnie do opinii Joë Nordmanna w tym względzie zob. idem, Aux vents d'histoire..., s. 171.

${ }^{14}$ Comment fut fabriqué Kravchenko?, „Les Lettres Françaises”, 13 XI 1947.

${ }^{15}$ F. Genevée, Le PCF et la Justice. Des origines, aux années cinquante, organisation, conceptions, militants et avocats communistes face aux normes juridiques, Clermont-Ferrand 2006, s. 374.

16 Archives de Georges Izard (archiwum w posiadaniu rodziny, niezinwentaryzowane), List Georgesa Izarda do Gérarda Bouteleau z 27 stycznia 1948.

17 J. Nordmann, Aux vents d'histoire..., s. 171: „Depuis deux ans, depuis que les communistes avaient été écartés du gouvernement, la presse communiste était souvent prise à part, et les procès de diffamation devenaient frequents” [„,Od dwóch lat, od kiedy komuniści zostali usunięci z rządu, prasa komunistyczna była często atakowana i zniesławienia były częste" - tłum. A.M.J.].

18 Archiwum Ministerstwa Spraw Zagranicznych (dalej: AMSZ), Zespół 8, wiązka 14, teczka 196, Raport Ambasady R.P. w Paryżu nr 23 z dnia 1 maja 1950 r., k. 237. 
który prowadził przeciwko innemu niezowraszczeńcowi, Janowi Valtinowi (prawdziwe imię i nazwisko: Richard Krebs), byłemu agentowi Kominternu i autorowi książki autobiograficznej Sans patrie ni frontières ${ }^{19}$. To właśnie Nordmann zachęcił FPK do rozwinięcia szerokiej kampanii przeciwko książce Krawczenki ${ }^{20}$. Prawdopodobnie jej częścią stało się zwerbowanie na świadków obrony szeregu znanych osobistości sympatyzujących z partią komunistyczna. W gronie wybrańców znaleźli się m.in.: noblista Frédéric Joliot-Curie, słynny pisarz Jean Bruller, lepiej znany pod pseud. Vercors oraz dawny szef francuskiej misji repatriacyjnej z ZSRR, gen. Ernest Petit ${ }^{21}$. Wielu spośród nich było zwolennikami utrzymania jedności z komunistami sięgającej czasów ruchu oporu i jak Vercors chciało przypomnieć w sądzie rolę, jaką „Les Lettres Françaises" odgrywało w środowisku konspirujących intelektualistów ${ }^{22}$.

Komunistyczny adwokat przewidział również ściagnięcie z ZSRR obywateli sowieckich, którzy mieli wystapić w roli świadków na tym procesie. Początek tej historii sięga chwili, gdy Nordmann zaczął zbierać dowody wskazujące na prawdziwość komunistycznych oskarżeń skierowanych przeciwko Krawczence. Bardzo szybko okazało się, że ani André Ullman, autor artykułu, który zaskarżył Krawczenko, ani Claude Morgan, dyrektor pisma, w którym ten tekst się ukazał, nie potrafili mu pomóc. W tej sytuacji Nordmann zwrócił się do ambasady ZSRR, która była najprawdopodobniej źródłem tych wszystkich enuncjacji ${ }^{23}$. Władze sowieckie potraktowały całą sprawę bardzo poważnie. W Moskwie podjęła pracę 3-4-osobowa komisja, która przygotowywała materiały na proces. Dodatkowo zaś na czas samej rozprawy sądowej powołano specjalna 14-osobowa komisję, która zajmowała się tą kwestią na miejscu w Paryżu ${ }^{24}$. Wiele wskazuje na to, że Nordmann konsultował z nia swoje poczynania, bowiem wspominał później, że uczęszczał regularnie na wieczorne zebrania $\mathrm{w}$ ambasadzie sowieckiej ${ }^{25}$. Ze strony francuskiej obronę przygotowywała specjalna komisja komunistyczna składająca się z 16 członków (w tym z 7 adwokatów), która obradowała pięć razy pomiędzy 7 I a 10 II 1949 r. Natomiast niemal do ostatniej chwili brakowało jakichkolwiek śladów bezpośredniego zainteresowania centralnych władz FPK tym zagadnieniem ${ }^{26}$.

${ }^{19}$ F. Genevée, op. cit., s. 375.

${ }^{20}$ Institut d'Histoire du Temps Présent (dalej: IHTP), Fonds Joë Nordmann, ARC 3015/12, Note au sécretariat du partie z 27 lutego 1948.

${ }^{21}$ Le procès Kravchenko. Compte rendu sténographique, oprac. G. Maurice, t. I, Paris 1949, s. $143-148$, t. II, s. $455-465$.

${ }^{22}$ Ibidem, t. I, s. $143-144$.

${ }^{23}$ IHTP, Fonds Joë Nordmann, ARC 3015, karton 12, Note au sécretariat du partie z 27 lutego 1948.

${ }^{24}$ AMSZ, Zespół 8, wiązka 24, teczka 312, List Jakuba Baumrittera do ministra Józefa Bermana [brak daty, dopisek z 19 X 1949], k. 13.

25 J. Nordmann, Aux vents d'histoire..., s. 181.

${ }^{26}$ Odnośnie do obrad komisji zob. IHTP, Fond de Joë Nordmann, ARC 3015/12, Réunion de la commission de travail „Lettres Françaises” c/Kravchenko chez Me Joë Nordmann 
Krawczenko i jego przedstawiciele (adwokat G. Izard oraz agent literacki Gérard Boutelleau) również starannie się przygotowywali. Dzięki ogłoszeniom prasowym zamieszczonym przez Boutelleau w prasie ukraińskiej i rosyjskiej, publikowanej w obozach dla dipisów (displaced persons) na terenie okupowanych Niemiec, zgłosiło się prawie 5 tys. ochotników gotowych świadczyć na rzecz Krawczenki ${ }^{27}$. Dysydent dokonał wśród nich starannej selekcji. Wiele osób wyeliminował z powodu ich przekonań i przeszłości. W gronie swoich świadków nie chciał mieć bowiem ani rosyjskich monarchistów, ani nazistów, ani dawnych kolaborantów, nacjonalistów ukraińskich czy jakichkolwiek emigrantów z Europy Środkowo-Wschodniej ${ }^{28}$. Z powodu swoich przekonań (dotyczących integralności terytorialnej Rosji, której Ukraina miała być etnograficzna częścia) popadł nawet w konflikt z ukraińskimi władzami emigracyjnymi ${ }^{29}$. Trzeba też przyznać, że dysydent typował na swoich świadków głównie ludzi prostych, w tym przede wszystkim Ukraińców, którzy znali go w przeszłości lub uczestniczyli w opisywanych przez niego wydarzeniach lub zjawiskach ${ }^{30}$. Wyjątek mógł uczynić co najwyżej dla francuskich i zachodnich intelektualistów (takich jak np. Albert Camus czy A. Koestler), ale ci ostatni odmówili mu swego poparcia, nie całkiem dowierzając w czystość jego intencji ${ }^{31}$. W rezultacie na procesie wystapiła tylko trójka mniej znanych Francuzów i jeden Włoch ${ }^{32}$.

7 janvier 1949, k. 1-4; Procès verbal d'une reunion tenue le 12 janvier 1949 chez Me Nordmann, k. 1-5; Réunion chez Nordmann 15 janvier 1949, k. 1-3; Commission du travail du 3.2.1949, k. 1-3; Réunion de la Commission de travail du 10 février 1949, k. 1-3. Skład wspomnianej komisji oraz kryteria dobierania do niej członków opisała w swojej pracy Marie Puyssier. Zob. idem, L'affaire Kravchenko. Etre avocat et communiste en France dans l'après guerre, mémoire de maîtrise sous la direction de Yoléne Dilas, Université Paris X, 2000, s. 59-66 (rękopis pracy dostępny jest w Institut d'Histoire du Temps Présent w Paryżu). Sekretariat Generalny FPK zainteresował się werdyktem z procesu dopiero 4 IV 1949. Zob. Archives du Communisme Français, 2 NUM 4/8 1949, Réunion du Sécretariat Géneral du 4 avril. Décisions: „10. Dénoncer le verdict du procès Kravchenko comme un acte d'hostilité à l'égard de l'URSS et comme un nouvel acte préparation à la guerre” [Zebranie Sekretariatu Generalnego z 4 kwietnia. Decyzje: „10. Wskazać na werdykt z procesu Krawczenki jako na akt przygotowujący wojnę" - tłum. A.M.J.].

${ }^{27}$ N. Berberova, L'affaire Kravchenko, Arles 1990, s. 13; G. Malaurie, E. Terrée, op. cit., s. 46.

${ }_{28}$ Archives de Georges Izard, List Wiktora Krawczenki do Georgesa Izarda z 7 lipca 1948.

${ }^{29}$ G. Malaurie, E. Terrée, op. cit., s. 61-63; V.A. Kravchenko, L'Épée et le serpent (J'ai choisi la justice!), Paris 1950, s. 37.

${ }^{30}$ Muzeum Narodowe w Krakowie (dalej: MNK), Archiwum Józefa Czapskiego, sygn. 2310, rkps, List Józefa Czapskiego do gen. Władysława Andersa z 7 lutego 1949.

${ }^{31}$ Odnośnie do odmowy Alberta Camus wystapienia na procesie zob. Archives de Georges Izard, List Georgesa Izarda do Gérard Boutelleau z 21 lipca 1946. Z kolei Raymond Aron, inny ważny krytyk ZSRR, postrzegał sprawę Krawczenki jako nie całkiem czysty proces. Zob. R. Aron, Widz i uczestnik, tłum. A. Zagajewski, Warszawa 1992, s. 179. Podobnie uważała Simone de Beauvoir, która podsumowała proces stwierdzeniem: „Wszyscy kłamia, nikt nie ma racji [...]”. Zob. eadem, Listy do Nelsona Algrena. Romans transatlantycki 1947-1964, tłum. J. Kozak, Warszawa 2000, s. 278.

${ }^{32}$ Le procès de Kravchenko..., t. I, s. 179-180, 240-250, t. II, s. 255-261. 
Dokonując takiego selektywnego wyboru swoich świadków, Krawczenko kreował oczywiście pewien (niepozbawiony wad) obraz własnej sprawy. Problemem okazał się np. fakt, że jego świadkowie prezentowali się mizernie (,twarze zmęczone, płaszcze wytarte, mali, brzydcy”) w zestawieniu z wielkimi intelektualistami francuskimi występującymi w imieniu komunistów ${ }^{33}$. Krawczenko tak, a nie inaczej dobierał rzeczników swojej sprawy, aby uniknąć oskarżeń o reakcyjność i faszyzm, ale nie udało mu się to. Wypominano im bowiem często, że uciekali z Niemcami przed Armią Czerwoną i nie chcieli wrócić do swojego kraju ${ }^{34}$. Jeden ze świadków obrony, niejaki Maurice Lampe, przewodniczacy prokomunistycznej francuskiej federacji byłych deportowanych ( Fédération Nationale des Déportés et Internés Résistants et Patriotes - FNDIRP), zapytywał nawet, dlaczego wśród osób powołanych przez Krawczenkę nie ma byłych więźniów z niemieckich obozów koncentracyjnych, w tym zwłaszcza z obozów zagłady ${ }^{35}$.

Sam proces opóźnił się wprawdzie niemal o rok, gdyż dysydent złożył jeszcze dwa pozwy przeciwko artykułom opublikowanym w „Les Lettres Françaises” ${ }^{6}$. Niemniej publiczność nie traciła zainteresowania sprawa, a koniunktura zimnowojenna wręcz wzrastała (m.in. w związku z blokadą Berlina) ${ }^{37}$.

Kiedy wreszcie rozprawa sądowa rozpoczęła się, obrady zamiast przewidzianych 9 dni trwały 2 miesiące (od 24 I do 22 III 1949) ${ }^{38}$. Na sali sądowej panował ogromny ścisk, obok setki dziennikarzy zasiedli znani intelektualiści, dyplomaci oraz damy z towarzystwa, a co najmniej kilkadziesiąt osób jeszcze stało $^{39}$. Wiele gazet francuskich zamieszczało też stenogramy z posiedzeń sądu ${ }^{40}$.

Jakie były przyczyny tak żywego zainteresowania tą sprawą? Najtrafniej ują to chyba Józef Mackiewicz, piszac: „proces ten zawiera wszystkie elementy podniecające dziś umysły całego świata. Od najbardziej prymitywnych, arcyludzkich kulis życia prywatnego, małżeńskiego, poprzez kuchnię literacko-wydawniczą do wielkiej polityki do aktualnego rozłamu między «wschodem» a «zachodem». Obejmuje sobą rozgłos pisarza, pieniądze dotyczy

${ }^{33}$ N. Berberova, op. cit., s. 18.

${ }^{34}$ Zob. np.: Le procès Kravchenko..., t. II, s. 162.

${ }^{35}$ Ibidem, t. I, s. 254.

${ }^{36} \mathrm{O}$ złożeniu pozwów przez Izarda zob. Archives de Georges Izard, List Georgesa Izarda do Wiktora Krawczenki z 30 lipca 1948.

${ }^{37}$ O narastaniu napięcia w związku z blokadą Berlina zob. V. Mastny, Stalin i zimna wojna. Sowieckie poczucie zagrożenia, tłum. M. Werner, Warszawa 2006, s. 114-115. Świadectwem nieustającego zainteresowania sprawą może być np. opublikowanie fikcyjnego wywiadu z Krawczenką w chwili, gdy nie chciał on w ogóle zabierać głosu. Zob. Archives de Georges Izard, List Georgesa Izarda do Wiktora Krawczenki z 16 czerwca 1948.

${ }^{38}$ N. Berberova, op. cit., s. 16.

${ }^{39}$ Ibidem, s. 8, 14.

${ }^{40}$ Początek tej tendencji miał dać podobno dziennik „L’Aurore”, zob. Proces Krawczenki, „Orzeł Biały” 1949, nr 9 (347). 
obcych wywiadów, rozwiera kulisy życia sowieckiego dla wielu bardziej egzotycznego niż [życie - A.M.J.] ludów notorycznie zwanych "egzotycznymi»"

W naturalny sposób dyskusja skupiała się na kwestiach opisanych w książce, a także na samym dziele, które - jak się później okazało - zostało napisane z pomoca ghostwritera (pisarza-widmo) ${ }^{42}$. Wielka sensację wzbudziło przybycie świadków sowieckich, w tym zwłaszcza pierwszej żony dysydenta, Zinaidy Gorłowej, która zarzuciła mu m.in. zaniedbanie własnego dziecka ${ }^{43}$. Komuniści systematycznie niszczyli wizerunek Krawczenki, oskarżając go o zdradę i dezercję, a on sam szkodził sobie, nie mogąc opanować kolejnych wybuchów gniewu ${ }^{44}$. Jego świadkowie (m.in. byli więźniowie łagrów, ofiary kolektywizacji i wielkiej czystki) wydawali się mało przekonujący. Komunistyczna obrona miała po swojej stronie wiele znakomitości, jednak większość z nich znała ZSRR co najwyżej z podróży i poświęcała swoją uwagę głównie postaci Krawczenki ${ }^{45}$. Paradoksalnie najsłabszych ogniwem obrony okazały się właśnie zeznania osób sprawdzonych z Kraju Rad, które nie podołały konfrontacji z adwokatami i świadkami oskarżenia. Wielokrotnie przyłapywano je na kłamstwach i przemilczeniach, a nawet na odmowie odpowiedzi na zadane pytania ${ }^{46}$. Mniej więcej po miesiącu opinia publiczna zaczęła ulegać znudzeniu procesem ${ }^{47}$.

Sytuację zmieniło pojawienie się wyjątkowego świadka oskarżenia, Margarete Buber-Neumann, wdowy pod jednym z przywódców niemieckiej partii komunistycznej (Deutsche Kommunistische Partei - KPD), Heinzu Neumannie. Jej mąż popadł w swoim czasie w niełaskę u Stalina, gdyż odważył się sprzeciwić jego dyrektywom i od początku lat trzydziestych aktywnie zwalczał narodowy socjalizm. Odbiło się to również na samym życiu Buber-Neumann, którą zesłano najpierw do łagru (na terenie Karagandy), a następnie w roku

${ }^{41}$ J. Mackiewicz, Proces Krawczenki, „Lwów i Wilno”, 13 II 1949, nr 105.

${ }^{42}$ Tym ghostwriterem był Eugene Lyons. Zob. G. Kern, The Kravchenko Case. One Man's War on Stalin, New York 2007, s. 162-164.

${ }^{43}$ Le procès de Kravchenko..., t. I, s. 467.

${ }^{44}$ Ibidem, t. I, s. 14, 51-52, t. II, s. 432 . O wybuchowym temperamencie Krawczenki zob. S. de Beauvoir, Listy do Nelsona Algrena..., s. 278. Również osoby życzliwe Krawczence zwracały uwagę na fakt, iż zbyt gwałtownymi wybuchami emocjonalnymi szkodzi on swojej sprawie, zob. np.: Archives de Georges Izard, Le principal héros de l'affaire (De notre envoyé permanent à Paris, par téléphone), R.F. Po latach Nordmann doszedł do wniosku, że Krawczenko był prawdopodobnie neuropata. Zob. J. Nordmann, Aux vents d'histoire..., s. 186.

${ }^{45}$ Zob. np. Le procès de Kravchenko..., t. I, s. 133, 216-219, 293-297, 402-414, 534-548, 632-658 oraz ibidem, t. II, s. 84-85.

${ }^{46}$ Zob np. ibidem, t. I, s. 480, 534-536, 603-604, t. II, s. 107-110.

${ }^{47} \mathrm{O}$ skargach francuskich gazet na monotonię zeznań w procesie Krawczenki zob. np. MNK, Archiwum Józefa Czapskiego, sygn. 2310, rkps, List Józefa Czapskiego do generała Władysława Andersa z 25 lutego 1949. Z relacji Beauvoir wynika, że już 16 lutego (czyli po przesłuchaniu połowy świadków) była ona znudzona procesem. Zob. eadem, Listy do Nelsona Algrena..., s. 281: „Proces Krawczenki wciąż trwa, wciąż tak samo idiotyczny [...]”. 
1940 wydano w ręce Niemców. Ci ostatni skierowali ją do obozu w Ravensbrück. Jej relacja poruszyła nawet lewicowych intelektualistów i komunistów. Sprawiła, że wiele osób uwierzyło w istnienie sowieckich obozów koncentracyjnych ${ }^{48}$.

Bilans procesu Krawczenki nie jest oczywisty, chociaż sąd przyznał mu w pierwszej instancji zwycięstwo, to zasądził relatywnie niskie odszkodowanie, m.in. z powodu chlubnej przeszłości wojennej jego przeciwników ${ }^{49}$. Simone de Beauvoir chyba słusznie uznała, że z propagandowego punktu widzenia żadna ze stron procesu nie wygrała, chociaż innego zdania był Jean Kardéland, wydawca książki sowieckiego dysydenta, który uważał, że Krawczenko przegrał swój proces ${ }^{50}$. Natomiast wyniki badań opinii publicznej wykazały, że $70 \%$ ankietowanych słyszało o procesie, połowa spośród nich deklarowała, że sprawa dysydenta budzi w nich sprzeczne uczucia, ale $35 \%$ na miejscu sędziego przyznałoby mu rację ${ }^{51}$.

W każdym razie wydarzenie to sprawiło, że komuniści zaczęli unikać podobnych konfrontacji. Postanowili w przyszłości bronić się nie tylko ofensywnie - obrona przez atak stanowiła stały element strategii komunistycznej, skodyfikował ją słynny adwokat Marcel Willard w książce La défense accuse (de Babeuf à Dymitrov) - ale również defensywnie, zwracając uwagę na fakt, iż francuski wymiar sprawiedliwości nie ma stosownych kompetencji, by sądzić ustrój innego państwa ${ }^{52}$. Dzięki przyjęciu takiej strategii uzyskali oni w sązie apelacyjnym obniżenie wysokości odszkodowania, które mieli zapłacić Krawczence, do wartości jednego symbolicznego franka ${ }^{53}$.

Innymi stosowanymi przez nich metodami defensywnymi stało się opóźnianie rozprawy sądowej (oczywiście pod warunkiem, że wydawało im się to korzystne) oraz paraliżowanie jej zgłaszaniem licznych zastrzeżeń

${ }^{48}$ Odnośnie do relacji Margarete Buber-Neumann zob. Le procès de Kravchenko, t. II, s. 261-281. Odnośnie do reakcji na jej wystapienie zob. eadem, Siła rzeczy, tłum. J. Pański, Warszawa 2009, s. 207; eadem, Listy do Nelsona Algrena..., s. 283-284; A. Wurmser, Fidèlement vôtre. Soixante ans de vie politique et littéraire, Paris 1979, s. 361; D. Desanti, Les Staliniens. Une expérience politique 1944-1956, Paris 1976, s. 169. Ciekawe relacje i wspomnienia dotyczące reakcji na wystapienie Buber-Neumann przedstawili Edgar Morin i Dominique Desanti w wywiadach udzielonych autorom filmu B. George i E. Blanchard, L'affaire Kravchenko. La guerre froide à Paris, ARTE France 2009 (film).

${ }^{49}$ E. Jaudel, L'aveuglement, l'affaire Kravchenko, Paris 2003, s. 301-315. Tekst wyroku zob. Le jugement de Kravchenko - Lettres Françaises, „Le Figaro”, 4 IV 1949.

${ }^{50}$ S. de Beauvoir, Siłq rzeczy..., s. 207; J. de Kardéland, op. cit., s. XXII.

${ }^{51}$ Te dane pochodzą z dwóch sondaży opinii publicznej: Sondages. Institut Français d'Opinion Publique, 1 avril 1949: VI. Le procès Kravchenko, s. 70-71; „Bulletin S.S.S.” (Service de Sondages et Statistiques), Cahiers n47, mars-avril 1949: Question $n^{\circ} 211$ : Que pensez-vous de la personnalité de Kravchenko, s. 703-706.

${ }^{52}$ Zob. np.: D. Rousset, Th. Bernard, G. Rosenthal, Pour la vérité sur les camps concentrationnaires. Un procès antistalinien à Paris, Paris 1990, s. 30.

${ }^{53}$ E. Jaudel, op. cit., s. 314-315. 
proceduralnych. Pierwsza godna odnotowania sugestia dotycząca opóźniania sprawy sądowej padła już w połowie procesu Krawczenki z ust sowieckiego ambasadora Aleksandra Bogomołowa ${ }^{54}$.

\section{Sprawa Davida Rousseta}

Nowa metoda walki pozwoliła skutecznie stawiać czoła naśladowcom sowieckiego dysydenta. Jednym $\mathrm{z}$ nich stał się lewicowy intelektualista francuski i dziennikarz David Rousset, który miał tę przewagę nad Krawczenką, że cieszył się wielkim szacunkiem we francuskim społeczeństwie. Za swoje uczestnictwo w ruchu oporu (z ramienia Komitetu IV Międzynarodówki) w 1943 r. został zesłany do niemieckich obozów koncentracyjnych (Buchenwald, Neuengamme i Porta Westfalica). Sławę zawdzięczał przede wszystkim opisaniu własnych doświadczeń w słynnej książce L'unnivers concentrationnaire. Chociaż sam w $1946 \mathrm{r}$. zerwał z partia trockistowska, to nie porzucił marksizmu ${ }^{55}$. Unikał też odwoływania się do idei lub koncepcji kontrowersyjnych dla ludzi ówczesnej francuskiej lewicy, takich jak antykomunizm czy totalitaryzm ${ }^{56}$. Zasłużył się również tym, że wraz z Jeanem-Paulem Sartre'em (w 1948 r.) stworzył efemeryczny ruch na rzecz neutralizmu (Rassemblement Démocratique Révolutionnaire - RDR $)^{57}$.

12 XI 1949 r. Rousset poruszył francuską opinię publiczna, publikując na łamach „Le Figaro Littéraire” apel do byłych więźniów obozów niemieckich, których wezwał do powołania międzynarodowej komisji majacej na celu przebadanie łagrów. W tekście swojego apelu odwoływał się m.in. do relacji łagrowych oraz do sowieckiego kodeksu pracy przymusowej. Odważył się też zasugerować podobieństwo byłych obozów nazistowskich i współczesnych obozów sowieckich ${ }^{58}$. Chociaż od razu został bardzo gwałtownie zaatakowany przez francuską prasę komunistyczna, to cały czas podkreślał, że chętnie widziałby komunistów w swojej komisji. Marzyło mu się stworzenie dyskursu neutralistycznego i apolitycznego, który poruszyłby całe społeczeństwo ${ }^{59}$.

Bezpośrednim powodem, dla którego wniósł oskarżenie o zniesławienie, było ukazanie się w „Les Lettres Françaises” obszernego artykułu polemicznego

${ }^{54}$ G. Malaurie, E. Terrée, op. cit., s. 60.

${ }^{55}$ E. Copfermann, David Rousset. Une vie dans le siècle, Paris 1991, s. 77-101.

${ }^{56}$ Zob. np.: J. Kowalewski, Sprawa łagrów na forum publicznym. Rozmowa z Davidem Rousset, „Wiadomości”, 26 II 1950.

57 O. Todd, Albert Camus. Biografia, tłum. J. Kortas, Warszawa 2009, s. 457-460.

${ }^{58} \mathrm{D}$. Rousset, Au sécours des déportés des camps soviétiques. Un appel aux anciens déportés des camps nazis, „Le Figaro Littéraire”, 12 XI 1949.

59 Bibliothèque de Documentation Internationale Contemporaine (dalej: BDIC), Archives de David Rousset, F delta 1880/61/2/1, List Davida Rousseta do Jamesa Burnhama z 16 stycznia 1950. 
Pierre'a Daixa, który zarzucił mu m.in. przytaczanie świadectw z obozów niemieckich, a nie sowieckich ${ }^{60}$.

Postawiło to Rousseta w bardzo kłopotliwej sytuacji, albowiem zacytował on anonimowe relacje i celowo pominął przy tym źródło ich pochodzenia - książkę La Justice soviétique opracowaną przez żołnierzy z 2 Korpusu. Obawiał się bowiem złej reputacji, która ta formacja zawdzięczała głównie intensywnej propagandzie komunistycznej. Andersowców oskarżano w ówczesnej prasie komunistycznej nie tylko o faszyzm i podżeganie do nowej wojny, ale również o popełnianie pospolitych przestępstw ${ }^{61}$. To najprawdopodobniej z tej przyczyny Rousset wzdrygał się początkowo przed nawiązaniem bezpośredniego kontaktu z gen. Andersem, pomimo iż bardzo potrzebował zarówno źródeł, jak i świadków z 2 Korpusu, by udowodnić swoje racje w sądzie. Drżał na samą myśl o tym, że materiały dowodowe mógłby przynieść na proces oficer $\mathrm{z}$ armii Andersa. Uważał, że osłabiłoby to wymowę jego sprawy ${ }^{62}$.

$\mathrm{O}$ pomoc w nawiązaniu kontaktów z otoczeniem gen. Rousset zabiegał w Instytucie Literackim u Józefa Czapskiego i Jerzego Giedroycia. Znalazł tam zrozumienie i daleko idące wsparcie również w innych kwestiach. Jerzy Giedroyc stworzył na potrzeby jego procesu pierwsza potencjalną listę polskich świadków. Kierował się przy tym wyraźnymi wskazówkami francuskiego dziennikarza. Wybierał byłych więźniów obozów sowieckich i więzień rosyjskich, którzy wyróżniali się lewicowymi przekonaniami, należeli do grona bezpartyjnych działaczy związkowych lub byli postaciami całkowicie apolitycznymi ${ }^{63}$. Przy czym Rousset, podobnie jak wcześniej Krawczenko, sygnalizował, że pewne kategorie osób nie mogą wystapić na jego procesie zarówno ze względu na swoją przeszłość, jak i przekonania. Do tego grona należeli policjanci, urzędnicy bezpieczeństwa i Oddziału II Sztabu Generalnego oraz „osoby jaskrawo wielkoprzemysłowe” czy też „wielkoziemiańskie” ${ }^{64}$. Taki dobór świadków wzbudził rzeczywiście opór w otoczeniu gen. Andersa. Pojawiła się tam nawet opinia, że członkowie Instytutu Literackiego „przesadzaja z ta lewicowością" ${ }^{65}$. Wynikało to z niezrozumienia sytuacji francuskich intelektualistów i kierowania się przede wszystkim kryteriami polskiej

${ }^{60}$ P. Daix, matricule 59. 807 à Mathausen. Répond à David Rousset. Vous ne ferez pas des déportés des camps nazis le porte - parole de la guerre d'Hitler, „Les Lettres Françaises”, 17 XI 1949.

${ }^{61}$ Zob. np.: R. Andrieu, Une enquête de „Ce Soir”. L'Armée Anders: Une formation militaire fasciste soutenue par Londres, elle possède des ramifications jusque dans la France de la libèration, „Ce Soir”, 21 I 1947.

62 Archiwum Instytutu Literackiego „Kultura” w Maisons-Laffitte (dalej: AIL ML), List J. Giedroycia do L. Łubieńskiego z 7 grudnia 1949.

${ }^{63} \mathrm{O}$ wsparciu ze strony Jerzego Giedroycia zob. np. AIL ML, List Jerzego Giedroycia do Ludwika Łubieńskiego z 29 listopada 1949 r. O wymaganiach Rousseta zob. IPMS, sygn. kol. 401/24, Sprawozdanie Janusza Kowalewskiego z 14 grudnia 1949 r.

${ }^{64}$ IPMS, sygn. kol. 419/51, List Jerzego Giedroycia do Ludwika Łubieńskiego z 7 grudnia 1949.

${ }^{65}$ AIL ML, List Jerzego Giedroycia do Józefa Czapskiego z 11 grudnia 1949 r. 
racji stanu oraz konserwatyzmem. Zresztą spór ten pozostał w dużej mierze jałowy, bowiem Polacy i tak nie mieli odegrać kluczowej roli w procesie (za wyjątkiem znanej i kojarzonej we Francji postaci Józefa Czapskiego) ${ }^{66}$.

Wydaje się, że z punktu widzenia Rousseta, który bardzo dobrze znał międzynarodowe środowiska lewicowe (w tym m.in. członków Kongresu Wolności Kultury, współpracowników wielu lewicowych antykomunistycznych pism oraz Davida Dallina - najbardziej wpływowego sowietologa w Stanach Zjednoczonych), polscy ani rosyjscy emigranci polityczni nie byli optymalnymi kandydatami na świadków ${ }^{67}$. Roussetowi bardziej zależało na odnalezieniu osób podobnych do Buber-Neumann, która mocno poruszyła opinię publiczna podczas procesu Krawczenki. Odszukał więc całe grono zachodnich intelektualistów, dawnych komunistów lub sympatyków komunizmu, którzy po przyjeździe do Związku Sowieckiego padli ofiara wielkiej czystki lub zostali uwięzieni w łagrach. Większość z nich spisała swoje wspomnienia, które $\mathrm{w}$ przededniu procesu przedrukowywano w prasie zarówno prawicowej, jak i lewicowej niekomunistycznej6 ${ }^{68}$ Z relacji syjonisty Julija Margolina, jedynego prawicowego świadka oskarżenia, wynika, że Rousset preferował też świadków pochodzenia żydowskiego z pobudek praktycznych, bowiem trudniej było im zarzucić faszyzm ${ }^{69}$. Przekonał się o tym boleśnie jeden z oskarżonych (C. Morgan, dyrektor tygodnika „Les Lettres Françaises”), kiedy wypominał Aleksandrowi Weissbergowi-Cybulskiemu jego niemieckość. Adwokat Rousseta, Théo Bernard zwrócił mu wówczas uwagę, że Weissberg był austriackim Żydem, a najbliższych członków jego rodziny (dwóch braci, ojca i żonę) zabili naziści ${ }^{70}$.

Strona komunistyczna postanowiła zapobiec procesowi lub co najmniej sparaliżować jego przebieg. W tym celu zrzekła się nawet prawa do przedstawienia

${ }^{66}$ Odnośnie do opinii otoczenia generała Andersa zob. AIL ML, List Jerzego Giedroycia do Ludwika Łubieńskiego z 29 listopada 1949. Co do niewielkiej roli, jaka polscy świadkowie odegrali w procesie, zob. Archiwum Emigracji Biblioteki Uniwersyteckiej UMK, Kolekcja Kazimierza Zamorskiego, List Kazimierza Zamorskiego do Mirosława Supruniuka z 8 sierpnia 2000. Co prawda, w pewnym momencie na liście świadków Rousseta znajdowali się przede wszystkim Żydzi i Polacy, jednak zadaniem tych drugich stało się jedynie dostarczenie dowodu na niewinność Rousseta. Nie zostali oni wyeksponowani ani nie budzili zainteresowania publiczności. Zob. AIL ML, List J. Giedroycia do J. Czapskiego z 11 grudnia 1949 r.

${ }^{67}$ O Kongresie Wolności Kultury zob. P. Grémion, Konspiracja wolności. Kongres Wolności Kultury w Paryżu (1950-1975), Warszawa 2004, s. 9, 25. Odnośnie do kontaktów i powiązań Rousseta zob. też: E. Copfermannn, op. cit., s. 108-110.

${ }^{68}$ Zob. np.: Première rencontre avec Georges Gliksman, „Combat”, 21 XI 1950; L'univers de la mort absurde. G. Gliskman me parle de Victor Alter, leader du Bund polonaise assasiné par N.K.V.D., „Combat”, 22 XI 1950; L'univers de la mort absurd. „J'ai vécu dans les prisons et les camps”, „Combat”, 23 XI 1950; L'univers de la mort. Ma vie et mes métiers dans la République soviétique de Komi, „Combat”, 24 XI 1950.

${ }^{69}$ J. Margolin, Pariżskij otczet, http://margolin-ze-ka.tripod.com/commentary09.html (dostęp: 11 IV 2011).

${ }^{70}$ G. Rosenthal, T. Bernard, D. Rousset, op. cit., s. 120. 
dowodu własnej niewinności. Stworzyła tym samym precedens prawny w sadzie francuskim. Tymczasem adwokaci Rousseta nalegali, by proces pomimo wszystko się odbył. Argumentowali przy tym, iż na drodze sądowej trzeba rozstrzygnać kwestię wiarygodności dokumentów, gdyż pomówienie spowodowało uszczerbek moralny u wielu osób, w tym także u ich klienta.

Sąd potrzebował niemal pięciu miesięcy, by podjać decyzję w tej kwestii. Ostatecznie 1 VII 1950 r. ustalono datę i długość trwania rozprawy ${ }^{71}$. Komuniści skorzystali ze swojego przyznania się do winy, by wymóc maksymalne skrócenie jej długości. W końcu uzgodniono, iż pomiędzy 25 XI 1950 a 7 I 1951 r. odbędzie się 10 przesłuchań świadków ${ }^{72}$.

Po rozpoczęciu procesu adwokaci komunistyczni, J. Nordmann i Paul Vienney złożyli szereg wniosków i odwołań, które całkowicie sparaliżowały obrady sądu podczas trzech pierwszych posiedzeń. Nordmann twierdził m.in., że sąd nie ma kompetencji do zajmowania się sprawą o zniesławienie Rousseta, która staje się powoli procesem instytucji funkcjonujących w ZSRR ${ }^{73}$. Pomimo że komuniści nie chcieli tego procesu, to dobrze się do niego przygotowali. Sekretariat Generalny FPK pomiędzy 20 XI a 18 XII 1950 r. pięciokrotnie podejmował decyzje dotyczące kształtu, jaki miała przybrać zarówno linia obrony, jak i kampania propagandowa, którą wszczęto wokół procesu. $\mathrm{Na}$ posiedzeniach Sekretariatu sugerowano także tematy, jakie obrona powinna poruszyć na rozprawie sądowej (w tym m.in. zalecono atak na pisma lewicy niekomunistycznej - „Le Populaire” i „Le Franc-Tireur”, bardzo zaangażowane $\mathrm{w}$ popieranie Rousseta $)^{74}$. Dodać należy również, że partie komunistyczne, zarówno polska, jak i sowiecka, dostarczyły na proces stosowne dossier dotyczące emigrantów z ich własnych krajów zeznających na procesie ${ }^{75}$.

Podczas tej rozprawy sądowej, inaczej niż miało to miejsce w procesie Krawczenki, przewaga intelektualna leżała po stronie świadków oskarżenia. Wśród świadków obrony nie pojawił się żaden ze sławnych sympatyków komunizmu (compagnon de route), a zeznawali jedynie intelektualiści ściśle związani z partia ${ }^{76}$. Rozprawę sądowa zdominowali zachodni intelektualiści świadczący dla Rousseta. Zaś dwaj Polacy (K. Zamorski i Władysław Bandrowski), którzy potwierdzili ostatecznie prawdziwość źródeł zacytowanych

71 BDIC, Archives de David Rousset, F delta 1880/61/2/2, List Davida Rousseta do Jerzego Gliksmana z 12 czerwca 1950.

72 Ibidem, List Davida Rousseta do Jerzego Gliksmana z 17 lipca 1950.

${ }^{73}$ G. Rosenthal, T. Bernard, D. Rousset, op. cit., s. 9-55.

${ }^{74}$ Archives du PCF, Secrétariat Général 2 NUM_4/8 1947-1949, Réunions du secrétariat du 20/XI/1950. Décisions, s. 3; ibidem, Réunions du secrétariat du 27/XI/1950. Décisions, s. 2-3, ibidem, Réunions du secrétariat du 4/XII/1950. Décisions, s. 2; ibidem, Réunions du secrétariat du 18/XII/1950. Décisions, s. 2.

${ }^{75}$ P. Daix, J'ai cru au matin, Paris 1976, s. 258.

76 T. Wieder, La Commision Internationale contre le regime concentrationnaire 1949-1959, rescapés des camps nazis combattent les camps de concentration, praca magisterska, mps, Paris 2002 (dostępna w Bibliotece École Normale Supérieure d’Ulm w Paryżu), s. 165. 
przez Francuza, pozostali jedynie świadkami drugiej kategorii ${ }^{77}$. Znaczacej roli nie odegrał też inny polski świadek, Józef Dolina, dawny naczelnik Wydziału Bezpieczeństwa Okręgowej Delegatury Rządu Polskiego w Londynie na Lublin ${ }^{78}$.

Są w wydanym wyroku uwzględnił (podobnie jak to miało miejsce w sprawie Krawczenki) okoliczności łagodzące wynikające zarówno z ideologicznego charakteru sporu o obozy, jak i z cierpień, które główny oskarżony, Daix znosił w obozach nazistowskich. Ostatecznie dwaj oskarżeni (autor tekstu i jego wydawca) zostali skazani na wypłacenie Roussetowi 100 tys. franków odszkodowania $^{79}$. Sacd apelacyjny w lipcu $1953 \mathrm{r}$. potwierdził ten wyrok ${ }^{80}$.

Nie dysponujemy niestety sondażami mówiącymi o skali odbioru procesu Davida Rousseta. Jednakże niewątpliwie znalazł on szerokie odbicie w prasie ${ }^{81}$. Jego inicjatywa poruszyła też głęboko przynajmniej niektórych lewicowych intelektualistów francuskich oraz przyczyniła się do ukazania się licznych publikacji książkowych dotyczacych spraw obozowych ${ }^{82}$.

\section{Sprawa tzw. Międzynarodówki zdrajców}

Emigranci polityczni z Europy Środkowo-Wschodniej zostali pominięci zarówno w inicjatywach Davida Rousseta, jak i Wiktora Krawczenki. Z pewnościa jednym z głównych powodów takiego stanu rzeczy był fakt, iż francuska opinia publiczna z nieufnościa odnosiła się do ich relacji, a w centrum jej zainteresowań znajdowały się kwestie sowieckie ${ }^{83}$.

${ }^{77}$ G. Rosenthal, T. Bernard, D. Rousset, op. cit., s. 127-133.

78 Ibidem, s. 168-170. Odnośnie do postaci Józefa Doliny zob. J. Zych-Dolina, Pamiętny lipiec $w$ Lublinie, „Kultura” 1950, nr 7-8, s. 166-188.

${ }^{79}$ G. Rosenthal, T. Bernard, D. Rousset, op. cit., s. 249-252.

${ }^{80}$ T. Wieder, op. cit., s. 167-168.

${ }^{81}$ Odnośnie do publikacji prasowych związanych z procesem zob. np.: S. de Beauvoir, Siła rzeczy..., s. 238. Regularnie ukazywały się też w prasie stenogramy sądowe, choć były one krótsze niż w te, które publikowano w okresie procesu Krawczenki.

${ }^{82}$ Inicjatywę Rousseta poparł m.in. Martin Louis-Chauffier, jeden z intelektualistów, którzy wcześniej zeznawali na rzecz komunistów w procesie Wiktora Krawczenki, zob. Devant l'opinion mondiale. David Rousset, Rémy Roure et Gaston Weil posent le problème des camps de concentration, „Le Figaro”, 16 XI 1949. Odnośnie do zeznań Martina Louisa-Chauffiera na procesie Krawczenki zob. Le procès de Kravchenko..., t. I, s. 66-70. Wspomniane publikacje książkowe to przede wszystkim wspomnienia świadków z procesu Davida Rouseta, zob. m.in.: E. Lipper, Onze ans dans les bagnes soviétique, Paris 1950, Général, El. Campensino, Le vie et la mort en URSS (1939-1949), Paris 1950; J. Margolin, La condition inhumaine. Cinq ans dans les camps de concentration soviétique, Paris 1949.

${ }^{83} \mathrm{O}$ zainteresowaniu opinii publicznej kwestiami głównie antysowieckimi zob. MNK, Archiwum Józefa Czapskiego, sygn. 2310, rkps, List Józefa Czapskiego do generała Władysława Andersa z 7 lutego 1949: „Zainteresowanie do spraw polskich, powiedziałbym wcześniej sowieckich, niewątpliwie wzrasta [...]”. Zresztą to właśnie ksiażce Czapskiego 
Jednakże niektórzy spośród francuskich intelektualistów i prawników zaciekawionych sytuacja międzynarodową pojmowali te kwestie szerzej. I tak np. czołowi adwokaci zaangażowani w sprawę Krawczenki zainteresowali się również kwestia polska. Główny adwokat obrony, komunista Nordmann ${ }^{84}$ pracował dla ambasady Polski Ludowej, a prawnik sowieckiego dysydenta, socjalista Izard bardzo chciał w swoim czasie wystapić jako obrońca w procesie socjalistów PPS-WRN ${ }^{85}$.

Sprawa „Międzynarodówki zdrajców” opierała się na założeniu, że można rozbudzić zainteresowanie francuskiej opinii publicznej losem emigrantów politycznych z Europy Środkowo-Wschodniej, a także na przeświadczeniu, że ich oficjalni przedstawiciele mogą trafić ze swoim przesłaniem do francuskiej opinii publicznej.

Od samego początku inicjatywa ta różniła się zasadniczo od dwóch poprzednich procesów, po pierwsze - podstawa jej rozpoczęcia nie były teksty napisane przez jej protagonistów, ale książka komunistycznego dziennikarza Renauda de Jouvenela L’internationale des traîtres (Międzynarodówka zdrajców), określająca wszystkich wybitniejszych przedstawicieli emigracji politycznej zza żelaznej kurtyny mianem zdrajców, co jeszcze potwierdzał i wzmacniał załączony do niej wstęp André Wurmsera ${ }^{86}$. Po drugie - inicjatorami procesu byli ludzie nieznani francuskiej opinii publicznej (w odróżnieniu od Krawczenki czy Rousseta) i do pewnego stopnia dość przypadkowi. Po trzecie zaś - niechcący zaalarmowali oni partie komunistyczne z wyprzedzeniem o swoich zamiarach.

Głównym inicjatorem tej affaire był niejaki Nicolas Dianu (dawny przedstawiciel Rumunii w ZSRR), który w lipcu 1949 r. natkną się na wspomniana książkę Jouvenela i ze zdumieniem zauważył, że na opublikowanej w niej liście „rumuńskich zdrajców” zajmuje on honorowe pierwsze miejsce ${ }^{87}$. Skłoniło go to do zwrócenia się do adwokata Krawczenki, Izarda z propozycja zorganizowania nowego procesu o zniesławienie, który zdobyłby rozgłos podobny

Terre inhumaine ( $N a$ nieludzkiej ziemi) francuski wydawca miał zarzucić nadmiar wątków polskich, które tamtejszego czytelnika nie były w stanie zainteresować. Ibidem, sygn. 2321, rkps, List Józefa Czapskiego do generała Kazimierza Wiśniewskiego z 15 maja 1948 r.

${ }^{84}$ O pełnieniu przez Nordmanna funkcji ambasadora Polski Ludowej zob. idem, Aux vents d’histoire..., s. 203. Zob. też: AMSZ, Zespół 8, wiązka 5, teczka 192, List chargé d’affaires Przemysława Ogrodzińskiego do szefów wszystkich konsulatów z 14 listopada 1950, s. 1-2.

${ }^{85}$ Ch. Dumas, Le procès des socialistes polonais, „Le Populaire”, 24 X 1947. O postaci Georges'a Izarda zob. J. Raymond, Georges Izard, w: Dictionnaire du mouvement ouvrier Français, éd. J. Maitron, Quatrième partie, 1914-1939, vol. XXXII: Hud à Kwa, Paris 1988, s. 90-91; E. Boysson, Georges Izard. Avocat de la liberté, Paris 2003, s. 7-110.

${ }^{86}$ R. de Jouvenel, L'internationale des traîtres, Paris 1948 (wyd. 2, Paris 1949); idem, Międzynarodówka zdrajców, Warszawa 1950.

${ }^{87}$ Les communistes démasqués. D’après les comptes rendus sténographiques du procès contre „L'Internationale des traîtres”, Paris 1953, s. 61-62. 
do spraw Krawczenki i Rousseta ${ }^{88}$. Pierwotnie Dianu i Izard zamierzali zjednoczyć wokół sprawy najważniejszych reprezentantów emigracji politycznej z Europy Środkowo-Wschodniej. Niestety politycy emigracyjni w większości nie chcieli wziaćc udziału w procesie zarówno z powodu znacznych kosztów sądowych (samo tylko wniesienie kaucji kosztować miało 3 mln franków), jak i z obawy, iż musieliby świadczyć razem z dawnymi kolaborantami. Doszli oni do takich wniosków po zapoznaniu się z praca Jouvenela, w której informacje o uznanych politykach emigracyjnych przemieszane były ze wzmiankami o prawdziwych kolaborantach z czasów II wojny światowej ${ }^{89}$.

Dianu pozyskał dla sprawy najpierw Georgiego Dymitrowa zwanego Gemeto (sekretarza MUCh (Międzynarodowej Unii Chłopskiej tzw. Zielonej Międzynarodówki) i przewodniczącego Bułgarskiego Komitetu Narodowego). Potem do tej inicjatywy przystapili również: polski płk Jan Kowalewski, rumuński dziennikarz Constantin Constantinescu (przedstawiciel gen. Rădescu, kierującego Rumuńskim Komitetem Narodowym w Nowym Yorku) oraz albański uchodźca Abaz Kupi ${ }^{90}$. Niestety ci dwaj ostatni musieli się później wycofać, gdyż pierwszy nie znalazł stosownej sumy pieniędzy na pokrycie kaucji, drugi zaś został oskarżony przez albański reżim o popełnienie zbrodni wojennych i nie zdołał zgromadzić dokumentacji, która pozwoliłaby mu oczyścić się z zarzutów ${ }^{91}$.

Sam Dianu nie dowierzał prawdopodobnie ambasadorowi rządu RP na uchodźstwie, Kajetanowi Dzierżykraj-Morawskiemu, który pośredniczył w kontaktach pomiędzy nim a polskim Londynem. Ambasador zajął bowiem bardzo sceptyczne stanowisko wobec całej inicjatywy. Z tego też powodu Dianu wysłał do swojego znajomego, wysokiego rangą urzędnika MSZ, Tadeusza Gwiazdoskiego list z informacja o przygotowywanym procesie, zawierający zachętę do zaangażowania się $\mathrm{w}$ tę kampanię antykomunistyczna. Kopertę zaadresował po prostu do "Sekretarza Generalnego Ministerstwa Spraw Zagranicznych w Londynie, Tadeusza Gwiazdoskiego". Brytyjska poczta skierowała tę przesyłkę omyłkowo do gmachu ambasady na Portland Place, który w tym czasie przejęli dyplomaci reprezentujący władze krajowe ${ }^{92}$.

${ }^{88}$ IPMS, sygn. A. 46/4, List Kajetana Dzierżykraj-Morawskiego do Ministra Spraw Zagranicznych z 16 lipca 1949.

${ }^{89}$ Ibidem, List Ministra Spraw Zagranicznych do Kajetana Dzierżykraj-Morawskiego z 28 lipca 1949; ibidem, List Kajetana Dzierżykraj-Morawskiego z 6 sierpnia 1949. Odnośnie do wysokości kaucji zob. J. Paul-Boncour, Préface, w: Les communistes démasqués..., s. XII.

${ }^{90}$ Ibidem, s. XVII.

${ }^{91}$ Ibidem, s. XII. Komuniści chcieli nawet sądownie dochodzić odszkodowania od Abaza Kupiego. Zob. ibidem, s. 23-24.

${ }^{92}$ Odnośnie do losów listu Dianu i jego błędnego przesłania do ambasady komunistycznych władz Polski zob. Biblioteka Polska w Paryżu (dalej: BPP), Archiwum Kajetana Dzierżykraj-Morawskiego, Tymczasowe 6, List Ambasadora Kajetana Dzierżykraj-Morawskiego do Ministra Spraw Zagranicznych z 2 grudnia 1952; J. Nordmann, Aux vents d'histoire..., s. 203. 
Komuniści zaalarmowani listem Dianu rozpoczęli aktywne przygotowania do procesu. Potraktowali zawarte w nim nadzieje na poważnie i zaczęli się obawiać, że ich przeciwnicy mogliby powołać na świadków „wybitne” osobistości spośród emigracji „reakcyjnej”. Gdyby do tego doszło - ich zdaniem - sprawa mogłaby zdobyć szerszy rozgłos, niż proces Krawczenki ${ }^{93}$.

Już tydzień po wpłynięciu pozwu do paryskiego sądu, dyrektor Wydziału VII MBP gen. Wacław Komar przesłał Jakubowi Bermanowi pierwsze materiały dotyczace przyszłej rozprawy sądowej ${ }^{94}$. Później ich zamawianiem i przesyłaniem do Francji zajęli się funkcjonariusze MSZ, którzy korzystali w dużej mierze ze źródeł dostarczonych im przez MBP i Oddział II Sztabu Generalnego ${ }^{95}$.

W prace bardzo aktywnie zaangażowali się również francuscy komuniści. Przy KC FPK powołano specjalną komisję, która miała zajmować się przygotowywaniem procesu. Kierowali nią kolejno dwaj członkowie tegoż $\mathrm{KC}$ - najpierw Johanny Berlioz-Bernier, a następnie Jean Chaintron ${ }^{96}$. Komuniści zamierzali prowadzić ofensywna kampanię propagandową skierowana „przeciwko zdrajcom narodu i ludu”. Chcieli przy okazji działać na rzecz pokoju oraz demokracji ludowych, których „narodowy charakter” zamierzali udowodnićp ${ }^{97}$. Jeszcze w styczniu 1950 r. Sekretariat Generalny FPK nakazał jednemu ze swoich członków, Étienne Fajonowi, „prowadzenie szerokiej kampanii [propagandowej] wobec opinii publicznej, stawianie pytań w naszej prasie przeciwko pozycjom przeciwników" ${ }^{98} .15$ lutego, prawdopodobnie pod wpływem moskiewskich nacisków, również w Warszawie powołano do życia specjalna komisję przy Wydziale Zagranicznym KC PZPR, w skład której weszło pięć osobistości z różnych resortów (Teodora Feder, Józef Różański, Stefan Staszewski, Witold Leder oraz Stanisław Gajewski). Zajmowała się

${ }_{93}$ AAN, sygn. 237/XXII/17, List ambasadora J.K. Wendla do Edwarda Ochaba z 28 sierpnia [1949], k. 1-2.

${ }_{94}$ Instytut Pamięci Narodowej, sygn. BU 01227/324, Pismo Dyrektora Departamentu II MSZ Stanisława Gajewskiego do szefa Sztabu Generalnego Wojska Polskiego, generała Wacława Komara z 21 października 1949, k. 17.

${ }_{95}$ Odnośnie do uzyskiwania przez MSZ akt z MBP i Oddziału II Sztabu Generalnego Wojska Polskiego zob. np. AMSZ, Zespół 8, wiązka 24, teczka 312, Pismo Dyrektora Departamentu II MSZ Stanisława Gajewskiego do Dyrektora w Ministerstwie Bezpieczeństwa Publicznego, Józefa Różańskiego z 21 października 1949, k. 18; ibidem, Pismo Dyrektora Departamentu II MSZ Stanisława Gajewskiego do szefa Sztabu Generalnego Wojska Polskiego, generała Wacława Komara z 21 października 1949, k. 17.

${ }^{96}$ Ibidem, List Jakuba Baumrittera do ministra Józefa Berman [b.d., dopisek z 19 X 1949], k. 11-13; ibidem, Notatka naczelnika Wydziału Romańskiego A. Mellera w sprawie Jouvenel-Würmser z 5 stycznia 1950.

97 Ibidem, Pismo Radcy Ambasady RP Przemysława Ogrodzińskiego do ambasadora Stefana Wierbłowskiego z 10 września 1949; ibidem, Pismo Jerzego Baumrittera do Jakuba Bermana [niedatowane, dopisek na liście pochodzi z 19 X 1949].

${ }^{98} \mathrm{O}$ decyzji sekretariatu KC FPK zob. Archives du Communisme Français, Sécretariat Géneral 2 NUM 4/8 1950-1953 du 10 janvier. Décisions. 
ona typowaniem świadków, opracowywaniem materiałów propagandowych oraz zbieraniem dokumentacji na potrzeby procesu. Komisja odbyła dziewięć posiedzeń. Pracowała do 21 III 1950 r..$^{99}$

Następnie prace komunistów gwałtownie wyhamowały. Wydaje się, że decydujący wpływ na nagła zmianę strategii miał wyrok sądu apelacyjnego w sprawie Krawczenki wydany jeszcze 24 I 1950 r. Co prawda oskarżeni komuniści zostali wówczas skazani na zapłacenie 1 franka symbolicznej grzywny, ale Jouvenel uznał taki wyrok za równoznaczny z uniewinnieniem ${ }^{100}$. Po usłyszeniu tego werdyktu adwokaci komunistyczni doszli do wniosku, że optymalnym rozwiąaniem byłoby uniknięcie procesu, a przynajmniej jego jak najdalsze odsunięcie w czasie ${ }^{101}$. Niewykluczone, że kierownictwa partyjne zarówno na Zachodzie, jak i na Wschodzie zareagowały na te postulaty z pewnym opóźnieniem.

W grudniu 1950 r. reaktywowano co prawda jeszcze raz przy KC FPK komisję do spraw tego procesu. Obradowała ona pod przewodnictwem Victora Johannesa, który zajmował się już do końca sprawą „Międzynarodówki zdrajców"102. Wydaje się jednak, że to właśnie komuniści wpłynęli znacząco na opóźnienie procesu, a nawet podjęli starania, by całkowicie uniknąć tej rozprawy sądowej. Ostatnią próbę w tym kierunku podjął już na samym początku procesu (4 II 1952) adwokat Nordmann. Jego starania nie przyniosły co prawda oczekiwanego rezultatu, ale dzięki złożeniu paru wniosków proceduralnych zdołał on sparaliżować pierwsze dwa dni obrad sądowych ${ }^{103}$. Trzeba przyznać, że tym razem koniunktura polityczna mu sprzyjała. Podnoszenie kwestii antysowieckich zaczęło być nie na rękę również władzom francuskim, które przeciwstawiały się remilitaryzacji Niemiec. W parlamencie francuskim dyskutowano właśnie kontrowersyjny projekt Europejskiej Wspólnoty Obronnej (EWO), który zakładał powołanie jedynie 12 dywizji niemieckich i utworzenie armii europejskiej ${ }^{104}$. Oczywiście wygrywanie kwestii represji

${ }^{99}$ Ibidem, Protokół z posiedzenia komisji w Wydziale Zagranicznym KC PZPR z 15 lutego 1950, k. 32-34; ibidem, Protokół z posiedzenia komisji w Wydziale Zagranicznym KC PZPR z 19 lutego 1950, k. 35-38; ibidem, Protokół z posiedzenia komisji w Wydziale Zagranicznym KC PZPR z 24 lutego 1950, k. 43-45; ibidem, Protokół z posiedzenia komisji w Wydziale Zagranicznym KC PZPR z 27 lutego 1950, k. 47-48; ibidem, Protokół z posiedzenia komisji w Wydziale Zagranicznym KC PZPR z 6 marca 1950, k. 50; ibidem, Protokół z posiedzenia komisji w Wydziale Zagranicznym KC PZPR z 9 marca 1950, k. 51; ibidem, Protokół z posiedzenia komisji w Wydziale Zagranicznym KC PZPR z 14 marca, k. 53.

100 E. Jaudel, op. cit., s. 314-315.

101 AMSZ, Zespół 8, wiązka 24, teczka 312, Pismo radcy ambasady Przemysława Ogrodzińskiego do dyrektora Departamentu II MSZ Stanisława Gajewskiego z 22 lutego 1950, k. 40-41.

102 Archives du Communisme Français, Sécretariat Géneral 2 NUM 4/8 1950-1953 du 26 décembre 1950, Décisions, Procès contre „L'Internationale des Traîtres: [...] 16. Refaire fonctionner la commission préveue pour la preparation de ce procès (Joannes)".

${ }^{103}$ Les communistes démasqués..., s. 7-26.

${ }^{104}$ Odnośnie do planów remilitaryzacji Niemiec i utworzenia EWO oraz francuskich odczuć w tym zakresie zob. M. Mikołajczyk, op. cit., s. 178-194. O wpływie tych wydarzeń na 
komunistycznych na Wschodzie mogło wówczas jedynie wzmocnić pozycję RFN, czego sobie nie życzono. W zmienionej sytuacji politycznej role odwróciły się. Tym razem to skarżacy, jak i sam sąd zainteresowali się odłożeniem obrad, tylko komuniści wyrażali odmienną opinię ${ }^{105}$. Ówczesna sytuacja polityczna była bowiem dla nich korzystna. W połowie procesu Nordmann zastanawiał się nawet, czy nie będzie w stanie wygrać procesu ${ }^{106}$.

Wpływ miały na to co najmniej jeszcze trzy inne okoliczności. Same postacie oskarżycieli okazały się łatwym celem dla ataków komunistów, polegajacych na ciagłym wykazywaniu „reakcyjności” emigrantów i ich związków z Niemcami ${ }^{107}$. W szczególności dotyczyło to płk. Kowalewskiego, dawnego pracownika Oddziału II Sztabu Generalnego, który w czasie II wojny światowej prowadził rozmowy z adm. Wilhelmem Canarisem (lub przynajmniej z człowiekiem, który się za niego podawał), dotyczące ewentualnego nawiązania współpracy polsko-niemieckiej ${ }^{108}$. Również działalność przedwojenna Kowalewskiego stała się kłopotliwą kwestią. Dzięki materiałom dostarczonym przez polskie władze reżimowe komunistyczny adwokat Nordmann bez trudu udowodnił, że płk Kowalewski nie mówił całej prawdy. Udało mu się wykazać, że oficer kłamał, gdy twierdził, że pełniąc funkcję polskiego attaché wojskowego w ZSRR (1928-1933), nie prowadził tam równocześnie pracy wywiadowczej. Z dokumentów, których uwierzytelnione kopie Nordmann pokazał w sądzie, wynikało wyraźnie, iż ta działalność stała się bezpośrednim powodem wydalenia Kowalewskiego z ZSRR. Tym samym adwokat doprowadził do idealnej sytuacji opisanej niegdyś przez głównego teoretyka komunistycznej linii obrony

proces zob. AMSZ, Zespół 8, wiązka 30, teczka 397, Wyciąg korespondencyjny nr 1926 z 25 lutego 1952, k. 53.

${ }^{105}$ Ibidem, Wyciag korespondencyjny nr 1233 (autorstwa Przemysława Ogrodzińskiego) z 6 lutego 1952, k. 10.

${ }^{106}$ Ibidem, Wyciąg z korespondencji nr 2187 z Paryża z dnia 2 marca 1952.

${ }^{107}$ Ibidem, Wyciag korespondencyjny nr 1715 (autorstwa Przemysława Ogrodzińskiego) z 20 lutego 1952, k. 50.

${ }^{108}$ Les communistes démasqués..., s. 190. Fakt ten był wówczas rzeczą powszechnie znana, bowiem brytyjski dziennikarz Ian Colvin opisał relację pułkownika na ten temat w książce pt. Canaris, notre allié secret, której fragmenty ukazały się w dzienniku „Le Monde” w 1951. Paradoksalnie to źródło pozostaje do dziś nieznane w kraju. Największy znawca działalności wywiadowczej Kowalewskiego, Jan Ciechanowski wspomina, że pogłosek o spotkaniu pułkownika $\mathrm{z}$ adm. Canarisem nie udało mu się zweryfikować. Zob. J. Ciechanowski, Putkownik Kowalewski kontakty $z$ wtadzami niemieckimi w czasie wojny, „Zeszyty Historyczne” 2003, nr 144, s. 79-80. Natomiast Nordmann nie znał memoriału zredagowanego przez pułkownika 24 VII 1940, w którym zakładał on możliwość nawiązania współpracy z Niemcami. Zob. B. Wiaderny, Niechciana kolaboracja. Polscy politycy i nazistowskie Niemcy w lipcu 1940 r., „Zeszyty Historyczne” 2002, nr 142, s. 132-137. Nie wiedział również, że Kowalewski w 1943 r. zwrócił się do Niemców z prośbą o udostępnienie mu materiałów o Katyniu, które chciał rozprowadzić wśród Polonii amerykańskiej. Zob. B. Wiaderny, Putkownik Kowalewski w Lizbonie - dwa epizody, „Zeszyty Historyczne” 2003, nr 144, s. 90-93. 
sądowej Marcela Willarda, twórcy koncepcji „obrony przez atak” - a mianowicie zaatakował jednego z powodów i zmusił go do składania wyjaśnieńn ${ }^{109}$. Dawne zastrzeżenia Rousseta, który nie życzył sobie, by na jego procesie pojawiali w roli świadków lub nawet tylko pośredników polscy oficerowie bądź dawni pracownicy Oddziału II Sztabu Generalnego, okazały się w pełni uzasadnione ${ }^{110}$.

Inną przyczyną klęski procesu był z pewnością brak znanych osobistości w gronie świadków, z dwoma może wyjątkami. Nie przez przypadek największe zainteresowanie prasy wzbudzili Hubert Ripka, były czechosłowacki minister handlu zagranicznego i Stanisław Mikołajczyk, były polski wicepremier ${ }^{111}$. Zreszta nawet zeznania tych ostatnich zrelacjonowano w gazetach francuskich w bardzo zdawkowy sposób. Ku głębokiej satysfakcji przedstawicieli polskiego reżimu w relacjach prasowych nie uwzględniono m.in. sensacyjnego doniesienia byłego polskiego premiera, który twierdził, że pogrom kielecki z 4 IV 1946 r. był jednym z czterech pogromów zaplanowanych przez funkcjonariuszy bezpieki (pozostałe miały się odbyć w Częstochowie, Poznaniu i Kaliszu) ${ }^{112}$.

Wreszcie w sprawie „Międzynarodówki zdrajców” brakowało jednego spójnego i prostego wątku przewodniego zrozumiałego dla Francuzów. Proces rozpadł się na rozważania dotyczące historii poszczególnych krajów Europy Środkowo-Wschodniej i w dużej mierze dotyczył wydarzeń z czasów II wojny światowej. Ponadto większość spośród osób zabierających głos stanowili emigranci polityczni bądź świadkowie z krajów demokracji ludowej, specjalnie

${ }^{109}$ Les communistes démasqués..., s. 128. Działalność wywiadowcza płk. Kowalewskiego w ZSRR jest faktem ustalonym ponad wszelka wątpliwość i stanowiła ona powód jego wydalenia z tego kraju w 1933 r. Można się natomiast spierać o to, czy podjęcie przez niego pracy wywiadowczej w ZSRR stanowiło działalność samowolną i przyniosło skromne rezultaty, jak utrzymuje Marcin Kruszyński. Zob. idem, Ambasada w Moskwie 1920-1939, Warszawa 2010, s. 223-224. Przeciwstawną opinię przedstawił Leon Ziaja w biogramie pułkownika, opublikowanym w Polskim Stowniku Biograficznym. Zacytował on tam następująca opinię ówczesnego zwierzchnika Kowalewskiego, ppłk. T. Pełczyńskiego, na temat jego pracy w Moskwie: „Z tej placówki [...] zdołał stworzyć pierwszorzędne źródło informacji dla Sztabu Głównego. W czasie swojej czteroletniej służby dostarczył licznych wiadomości o stanie wojska i państwa ZSRR”. Zob. L. Ziaja, Jan Kowalewski, PSB, t. XIV, Wrocław 1968-1969, s. 524-525.

110 Odnośnie do członków Oddziału II Sztabu Generalnego zob. AIL ML, List Jerzego Giedroycia do Ludwika Łubieńskiego z 27 grudnia 1950 r. Odnośnie do oficerów zob. IPMS, sygn. kol. 419/15, List Jerzego Giedroycia do Ludwika Łubieńskiego z 7 grudnia 1950 r.

111 AMSZ, Zespół 8, wiązka 30, teczka 397, Wyciag korespondencyjny nr 2221 z 3 marca 1952 , k. 77.

112 Ibidem, Wyciag korespondencyjny nr 2187 (autorstwa Przemysława Ogrodzińskiego) z dnia 2 marca 1952, k. 76: „Niektóre deklaracje Mikołajczyka prasa reakcyjna wykorzystała, lecz ogólnie nie poświęciła mu dużo miejsca, nie zmieniła ona swego nastawienia do procesu, a niektóre kłamliwe oświadczenia Mikołajczyka /Kielce/ była zmuszona wręcz przemilczeć”. Wypowiedź Mikołajczyka o zaplanowanych pogromach można odnaleźć w: Les communistes démasqués..., s. 300. 
wydelegowani na ten proces. Wystapiło tam jedynie kilku Francuzów ${ }^{113}$. W przypadku świadków ściagniętych z Polski Ludowej zarówno treść ich wypowiedzi, jak i zadawanych im pytań była starannie nadzorowana przez specjalnie oddelegowanych urzędników (głównie przez Adama Mellera), a za ich pośrednictwem - przez polskie czynniki rządowe ${ }^{114}$. W ten sposób uniknięto z pewnością konfuzji, w jaką popadali nieraz świadkowie przysłani zza żelaznej kurtyny na proces Wiktora Krawczenki.

Sąd skazał oskarżonych na zapłatę 1 symbolicznego franka odszkodowania i 12 tys. franków grzywny ${ }^{115}$. W wyniku rozprawy apelacyjnej, która miała miejsce w lutym 1953 r., wyrok ten potwierdzono ${ }^{116}$.

Sami oskarżeni - Renaud de Jouvenel i André Wurmser - do dziś nie zmienili swoich przekonań. Jouvenel sądzi, że wiele poruszanych na tym procesie kwestii pozostaje w zawieszeniu ${ }^{117}$. Natomiast Wurmser pod koniec lat siedemdziesiątych uznał, że niczego by nie zmienił we wstępie, który napisał do L’internationale des traîtres ${ }^{118}$. Również wśród oceniajacych te wydarzenia zwolenników strony skarżącej zdania były podzielone. Świadek oskarżenia Zygmunt Zaremba i adwokat bułgarskiego powoda Dymitrowa twierdzili, że proces pozwolił Francuzom lepiej zrozumieć położenie Europy Środkowo-Wschodniej ${ }^{119}$. Innego zdania był Roman Fajans, paryski korespondent „La Libre Belgique” i „Dziennika Polskiego i Dziennika Żołnierza”. Utrzymywał on, że francuska publiczność pogubiła się w zawiłych problemach dotyczących Europy Środkowo-Wschodniej ${ }^{120}$.

Z perspektywy czasu widać, że zapamiętano tylko dwa pierwsze procesy, a o trzecim zupełnie zapomniano ${ }^{121}$. Jednak trzeba też przyznać, że dwie pierwsze sprawy zostały skonstruowane z myślą o francuskiej publiczności. Rousset starał się w szczególności trafić do francuskiej inteligencji lewicowej, której sam był przedstawicielem. Ponadto obydwa te procesy miały też swoje wątki przewodnie. Sprawa Krawczenki koncentrowała się wokół jego osoby, a proces Rousseta wokół problemu obozów sowieckich. Natomiast sprawa „Międzynarodówki zdrajców” była niespójna, rozpadła się na wiele

${ }^{113}$ Wśród 38 świadków przesłuchanych na procesie tzw. Międzynarodówki zdrajców znajdowało się zaledwie 5 Francuzów i 1 Anglik. Zob. Les communistes démasqués..., passim.

114 AMSZ, Zespół 8, wiązka 30, teczka 397, Wyciag korespondencyjny nr 1715 (autorstwa Przemysława Ogrodzińskiego) z 20 lutego 1952, k. 50.

${ }^{115}$ Les communistes démasqués..., s. 648-649.

116 Ibidem, s. 671-679.

${ }_{117}$ R. de Jouvenel, Confidences d'un ancien sous-marin du PCF, Paris 1980, s. 85-86.

118 A. Wurmser, op. cit., s. 120.

119 J.P. Aujol, Un avocat dans le siècle, de Poincaré à Mitterand, Paris 1989, s. 184. BPP, akc. 4184, Archiwum Zygmunta Zaremby, V/133, Résumé z procesu przeciwko komunistycznym oszczercom z 2 marca 1952, s. 1-3.

120 AMSZ, Zespół 8, wiązka 30, teczka 397, Wyciagg korespondencyjny nr 2221 z 3 marca 1952, k. 77-78.

${ }^{121}$ Ibidem, Komunikat PAP z 4 lutego 1952, k. 2. 
szczegółowych wątków, a emigranci polityczni nawet nie usiłowali narzucić komunistom francuskim własnego jednowątkowego i prostego dyskursu. Nie starali się też stworzyć obrazu przypadającego do gustu i przekonań francuskiej lewicy bądź opinii publicznej. W tym przede wszystkim dopatrywałabym się przyczyn ich ostatecznej klęski. Z perspektywy czasu można uznać, że największe zwycięstwo odniósł chyba Rousset, którego dawni przeciwnicy z sali sądowej (Nordmann, Daix) pokajali się po latach. Już po ukazaniu się we Francji relacji Aleksandra Sołżenicyna o Gułagu, zabiegali o pojednanie z Roussetem oraz o jego przebaczanie ${ }^{122}$. Natomiast Krawczenko do dziś bywa krytycznie oceniany, choć trzeba przyznać, że to jego sprawa cieszyła się największym rozgłosem i to on zapoczątkował cykl opisywanych tu wydarzeń.

\section{Streszczenie}

Po zakończeniu II wojny światowej scena polityczno-intelektualna we Francji została zdominowana przez lewicowców, którzy żywili nie tylko głęboki podziw dla roli, jaką komuniści odegrali w rodzimym ruchu oporu, ale i doceniali zasługi Armii Czerwonej w pokonaniu III Rzeszy. Zaś politycy, którzy nie ulegali podobnym sentymentom, chcieli, by Francja zachowała rolę pośrednika między mocarstwami - USA i ZSRR. Z tych powodów odnoszono się bardzo nieufnie do wydawnictw antysowieckich, które drukowane były nieraz poza granicami Francji. Emocje te zaczęły ulegać zmianie dopiero wiosną i latem 1947 r., kiedy to francuscy politycy zdecydowali się zaangażować w zimnowojenny spór po stronie USA. Inny czynnik, który wpłyną na zmianę postaw wśród francuskich elit, stanowiło pojawienie się świadectw antysowieckich o lewicowym wydźwięku. Pierwszą taką książką była niewątpliwie Ciemność $w$ południe Arthura Koestlera, choć tę cechę można też przypisać największemu bestsellerowi tamtych czasów, czyli autobiografii Wiktora Krawczenki zatytułowanej Wybratem wolność. Krawczenko stał się całkiem świadomie twórcą zupełnie nowej formy debaty publicznej skierowanej przeciwko komunistom, kiedy to wytoczył przeciwko nim proces o zniesławienie. Wykorzystał on francuską scenę sądowa, by przeciwstawić relacjom francuskich intelektualistów świadectwa uchodźców z ZSRR (w tym głównie z Ukrainy), którzy znali sowiecki system represji z autopsji. Ten proces zyskał olbrzymi rozgłos. Krawczenko wygrał w sądzie, choć wielu uważało jego sukces za pyrrusowe zwycięstwo. Niemniej znalazł on naśladowców m.in. w osobach Davida Rouseta i w oskarżycielach z procesu tzw. Międzynarodówki zdrajców. Były to dwa skrajnie różne wydarzenia. O ile bowiem proces francuskiego lewicowego intelektualisty, jakim był Rousset, zdołał jeszcze poruszyć (choć w mniejszym stopniu) opinię publiczną i intelektualistów, to organizatorom kolejnego procesu już się to nie udało. Wpłynęło na to z pewnością kilka czynników, a wśród nich wymienić należy dużą różnorodność tematyczna wątków poruszanych na procesie „Międzynarodówki zdrajców”, podczas gdy zarówno proces Krawczenki, jak i sprawa sądowa Rousseta skupiły się jedynie na wybranych zagadnieniach: pierwszy dotyczył głównie życia głównego protagonisty, drugi - funkcjonowania obozów sowieckich. Inny powód klęski ostatniego procesu stanowił fakt, że jego organizatorom nie udało się zmobilizować ważnych osobistości, które gotowe byłyby się wypowiedzieć o terrorze stalinowskim. Wreszcie francuska opinia publiczna od początku interesowała się bardziej sytuacją w ZSRR niż wydarzeniami majacymi miejsce w Europie Środkowo-Wschodniej.

122 J. Nordmann, David Rousset contre „Les Lettres Françaises”. Après le coup (Entretien), „Lignes”, V 2000, s. 110; P. Daix, Tout mon temps, Paris 2001, s. 465-466, 474. 


\section{Strategies and methods of informing the French public opinion about Stalinist terror behind the Iron Curtain on the example of political trials in 1949-1952}

After the end of World War Two the political and intellectual scene in France was dominated by left-wingers who not only admired the role played by communists within their movement, but also appreciated the contribution of the Red Army to the defeat of the Third Reich. Those politicians, on the other hand, who did not surrender to such sentiments, wanted France to play the role of mediator between the United States and the Soviet Union. For those reasons anti-Soviet publications, occasionally published outside France, were approached with great reserve and distrust. The atmosphere began to change in the spring and summer of 1947 , when French politicians decided to back up the US. Another factor influencing the change in the attitude of French elites were the emergence of anti-Soviet testimonies of leftist character. The first such publication was undoubtedly Arthur Koestler's Darkness at Noon, and then the best-selling book at that time, Victor Kravchenko's autobiography I Chose Freedom. Kravchenko himself quite deliberately created a new form of public debate directed against communists, when he brought a case against them for libel. He used the French courtroom to confront reports by French intellectuals with testimonies of refugees from the USSR (mainly from Ukraine), who personally experienced the Soviet political system. The trial gained large publicity. Kravchenko won in court, even if many regarded his success as a Pyrrhic victory. Nevertheless, he had some followers, including David Rousset or prosecutors of the so-called trial of the "International of traitors". But while the trial of the French leftist intellectual Rousset did move (even if not so much) the French public opinion of that time, the organisers of the second trial failed in this matter. This certainly had several reasons, including a broad array of topics brought up at the trial of the "International of traitors", whereas both Kravchenko's and Rousset's trials focused on selected problems, the first being Kravchenko's life, and the latter - operations of Soviet gulags. Another reason of the failure of the "International of traitors" suit was the fact that the organisers were unable to mobilise important public figures to speak about Soviet terror. And finally, the French public opinion was more interested in the situation in the Soviet Union than in events taking place in Central Eastern Europe.

\section{Bibliografia}

Affaires, scandales et grandes causes. De Socrate à Pinochet, ed. L. Boltanski et al., Paris 2007. Beevor A., Cooper A., Paryż wyzwolony, tłum. J. Małecki, Kraków 2015.

Boysson E., Georges Izard. Avocat de la liberté, Paris 2003.

Ciechanowski J., Putkownik Kowalewski kontakty z władzami niemieckimi $w$ czasie wojny, „Zeszyty Historyczne” 2003, nr 144, s. 52-88.

Genevée F., Le PCF et la Justice. Des origines, aux années cinquante, organisation, conceptions, militants et avocats communistes face aux normes juridiques, Clermont-Ferrand 2006.

Goetschel P., Toucheboeuf B., La IVe République. La France de la Libération à 1958, Paris 2004.

Grémion P., Konspiracja wolności. Kongres Wolności Kultury w Paryżu (1950-1975), Warszawa 2004.

Jarosz D., Pasztor M., Robineau, Bassaler i inni. Z dziejów stosunków polsko-francuskich $w$ latach 1948-1953, Toruń 2001.

Jaudel E., L'aveuglement, l'affaire Kravchenko, Paris 2003.

Kern G., The Kravchenko Case. One Man's War on Stalin, New York 2007.

Kruszyński M., Ambasada w Moskwie 1920-1939, Warszawa 2010.

Le temps de la guerre froide. Du rideau de fer à l'effondrement du communisme, éd. M. Winock, Paris 1994. 
Malaurie G., Terrée E., L’affaire Kravchenko. Paris 1949, le Goulag en correctionnelle, Paris 1991.

Mastny V., Stalin i zimna wojna. Sowieckie poczucie zagrożenia, tłum. M. Werner, Warszawa 2006.

Mikołajczyk M., Polityka Francji wobec ZSRR w latach 1944-1955, Poznań 2004.

Ory P., Les collaborateurs 1940-1945, Paris 1976.

Puyssier M., L'affaire Kravchenko. Etre avocat et communiste en France dans l'après guerre, mémoire de maîtrise sous la direction de Yoléne Dilas, Université Paris X, 2000 (rkps dostępny w Institut d'Histoire du Temps Présent w Paryżu).

Raymond J., Georges Izard, w: Dictionnaire du mouvement ouvrier Français, éd. J. Maitron, Quatrième partie, 1914-1939, vol. XXXII: Hud à Kwa, Paris 1988, s. 90-91.

Rigoulot P., Les Paupières lourdes. Les Français face au goulag. Aveuglement et indignations, Paris 1991.

Rioux J., L'affaire Kravchenko, w: Stalin à Paris, red. N. Dioujeva, F. Georges, Paris 1992, s. $151-153$.

Scammell M., Koestler. The Indispensable Intellectual, London 2009.

Todd A., Albert Camus. Biografia, Warszawa 2009.

Wall I., L’influence américaine sur la politique française 1945-1954, Paris 1989.

Wiaderny B., Niechciana kolaboracja. Polscy politycy i nazistowskie Niemcy w lipcu 1940 r., „Zeszyty Historyczne” 2002, nr 142, s. 131-140.

Wiaderny B., Putkownik Kowalewski w Lizbonie - dwa epizody, „Zeszyty Historyczne” 2003, nr 144 , s. 88-102.

Wieder T., La Commision Internationale contre le regime concentrationnaire 1949-1959, rescapés des camps nazis combattent les camps de concentration, praca magisterska, mps, Paris 2002 (dostępna w Bibliotece École Normale Supérieure d’Ulm w Paryżu).

Winock M., Le siècle des intellectuels, Paris 1999.

Ziaja L., Jan Kowalewski, PSB, t. XIV, Wrocław 1968-1969, s. 524-525.

Biog ram: Anna Maria Jackowska - dr; zajmowała się dziejami polskiej emigracji we Francji. Obroniła w Instytucie Historii PAN doktorat zatytułowany Polskie świadectwa o terrorze stalinowskim przekazywane francuskiej opinii publicznej $w$ latach 1947-1951. $\mathrm{Na}$ jego podstawie przygotowała książkę zatytułowana „Sowiety na ławie oskarżonych”. Udziat Polaków w propagandowej zimnej wojnie we Francji w latach 1947-1952 (w druku). E-mail: anna.maria.jackowska@gmail.com. 